\title{
Effects of dietary baker's yeast extract on the growth, blood indices and histology of Nile tilapia (Oreochromis niloticus L.) fingerlings
}

by Hassaan, M.S., Mahmoud, S.A., Jarmolowicz, S., ElHaroun, E.R., Mohammady, E.Y. and Davies, S.J.

Copyright, publisher and additional information: This is the author accepted manuscript. The final published version (version of record) is available online via Wiley. This article may be used for non-commercial purposes in accordance with Wiley Terms and Conditions for Self-archiving.

Please refer to any applicable terms of use of the publisher.

DOI: https://doi.org/10.1111/anu.12805

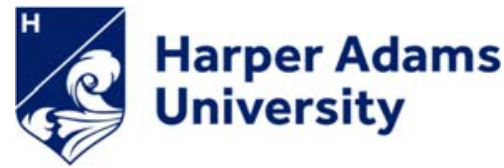


1 Effects of dietary baker's yeast extract on the growth, blood indices, and histology of Nile

2 tilapia, Oreochromis niloticus L, fingerlings

3

$4 \quad$ M.S. Hassaan ${ }^{1}$ S. Mahmoud ${ }^{1}$ S. Jarmolowicz ${ }^{2}$ E.R. El-Haroun ${ }^{3}$ E.Y. Mohammady ${ }^{1}$ S.J.

5 Davies $^{4 *}$

6

M. HASSAAN

$7 \quad{ }^{1}$ Aquaculture Division, Fish Nutrition Research Laboratory, National Institute of

8 Oceanography and Fisheries (NIOF), Cairo, Egypt

9

S. MAHMOUD

$10 \quad{ }^{1}$ Fish Disease Research Laboratory, National Institute of Oceanography and Fisheries

11 (NIOF), Cairo, Egypt

\section{S. JARMOŁOWICZ}

13

${ }^{2}$ Department of Ichthyology, Stanisław Sakowicz Inland Fisheries Institute, Poland

14

\section{E. El-HAROUN}

15

${ }^{3}$ Division of Aquaculture, College of Agriculture, Cairo University, Cairo, Egypt

16

\section{MOHAMMADY}

$18{ }^{1}$ Aquaculture Division, Fish Nutrition Research Laboratory, National Institute of

19 Oceanography and Fisheries (NIOF), Cairo, Egypt

${ }^{4}$ Fish Nutrition and Aquaculture, Department of Animal Production, Welfare and Veterinary

24 Email: sdavies@harper-adams.ac.uk 


\section{Abstract}

Nile tilapia, Oreochromis niloticus (average initial weight, $5.91 \pm 0.04 \mathrm{~g}$ ) were fed four isonitrogenous and isolipidic diets for 84 days. The diets contained four levels of yeast extract (CW-I) rich in nucleotides and $\beta$-glucan: 0 (control), 5, 10, and $15 \mathrm{~g} \mathrm{~kg}^{-1}$ diet. Weight gain increased linearly while the feed conversion ratio decreased linearly with increasing levels of yeast extract. The diet containing $15 \mathrm{~g} \mathrm{~kg}^{-1}$ yeast extract resulted in significantly better $(\mathrm{P}<0.05)$ specific growth rates and protein efficiency ratios. No significant $(\mathrm{P}>0.05)$ differences were found in dry matter, protein, lipid, or ash contents or in hematocrit, hemoglobin, or total protein contents among the treatment groups. Blood sample profiles showed an increase in white and red blood cells in fish fed $15 \mathrm{~g} \mathrm{~kg}^{-1}$ yeast extract in comparison with the other treatment groups. The fish fed the diets with 10 and $15 \mathrm{~g} \mathrm{~kg}^{-1}$ yeast extract had significantly higher albumin and globulin levels than did the control group, while decreased levels of cholesterol and triglycerides, aspartate aminotransferase, and alanine aminotransferase were noted in fish fed the diet with $15 \mathrm{~g}$ yeast extract $\mathrm{kg}^{-1}$. Histological analysis of the liver and intestine in fish fed control diet showed substantial damage and even necrotic lesions. Only in fish fed diets supplemented with the highest amount of yeast extract was the structure of the hepatocytes and villi almost unchanged, which indicated that the yeast nucleotides could improve hepatic function and promote liver and gut restoration.

Keywords: Yeast extract, nucleotides, growth, hematology, histology, Oreochromis niloticus 


\section{Introduction}

One of the main challenges in achieving productive, feasible, sustainable aquaculture is to develop alternative prophylactics that could help to maintain high animal welfare standards that foster better production and higher profits. Fish diets should not only provide the essential nutrients that are required for normal physiological functioning, but they should also serve as the medium by which fish receive other components that affect their health (Li and Gatlin 2004). Baker's yeast, or Saccharomyces cerevisiae yeast, is a particularly important natural bio-product since it contains immunostimulating compounds such as nucleotides, $\beta$ glucan, mannan oligosaccharides, and chitin, and it has been proved to influence the fish immune response and to promote growth (Abdel-Tawwab 2012). On the other hand, commercial brewer's yeast is an inactive yeast (dead yeast cells) that is a by-product of brewing. The cell wall, which can comprise $20-25 \%$ of the dry weight of the cell, consists of about $85-90 \%$ polysaccharide. The polysaccharide component consists of a mixture of mannan, glucan, and small amounts of chitin (Nguyen et al. 1998). Numerous studies have focused on the effect of mannan oligosaccharides, glucans, and chitin on the immune response in different fish species, and indicate that these compounds strongly stimulate fish immune systems (Couso et al. 2003, Torrecillas et al. 2007). Yeast extract is the product of the enzymatic digestion of the yeast cell constituents by endogenous and exogenous yeast enzymes (Bekatorou et al. 2006). Yeast extract is considered an important source of nucleotides in the form of nucleic acids (Ferreira et al. 2010). Nucleotides are low molecular weight biological compounds that play important roles in essential physiological and biochemical functions (Carver and Walker 1995). Nucleotides are synthesized de novo in most tissues, but some immune and intestinal cells lack or cannot execute this process and depend on exogenous dietary supply (Quan 1992). Hence, the administration of pure nucleotides guarantees increased availability to the body at times of high demand for various 
physiological activities (Biswas et al. 2012). High dietary concentrations of nucleotides can also compromise growth and protein accretion (Peres and Oliva-Teles 2003, Oliva-Teles et al. 2006). It has been demonstrated that nucleotides added to basal diets can affect positively fish growth (Li et al. 2005), innate and adaptive immune responses (Sakai et al. 2001, Li et al. 2004, Li and Gatlin 2004) and disease resistance (Barros et al. 2013). However, most experiments on the effect of baker's yeast on the growth and physiological condition in different fish species have focused on investigating the effects of whole yeast cells, or of bioactive components that were isolated from whole yeast cells, such as nucleotides or $\beta$ glucan. To the best of the authors' knowledge, there is little information regarding the effect on fish immune responses of baker's yeast extract that contains both nucleotides and $\beta$-glucan. Therefore, this study was designed to evaluate the efficacy of baker's yeast extract (CW-I) supplementation on the growth, feed utilization, hematological, and histological and biochemical blood parameters of Nile tilapia, Oreochromis niloticus L.

\section{Materials and methods}

Experimental design and culture technique

Nile tilapia, Oreochromis niloticus fingerlings were collected from the Fish Research Station, El-Kanater El-Khayria, National Institute of Oceanography and Fisheries, Cairo, Egypt and held for two weeks in indoor fiberglass tanks for acclimation. Prior to the beginning of the experiment, the fish were acclimatized to experimental conditions and manually fed a commercial diet (300 $\mathrm{g} \mathrm{kg}^{-1}$ crude protein) twice daily to apparent satiation for seven days. After acclimatization, 600 Nile tilapia fingerlings with an average initial body weight of $5.91 \pm 0.04 \mathrm{~g}$ were stocked into 12 concrete ponds $\left(0.5 \mathrm{~m}^{3}\right)$. Each pond was stocked with 100 fish and maintained in freshwater at $26{ }^{\circ} \mathrm{C}( \pm 2.0)$ under a natural photoperiod. All dietary treatments were tested in triplicate, and each pond was considered to be an experimental unit. During the experiment, the fish were fed manually two times daily to 
apparent satiation at 09:00 and 15:00. The total fish weight in each pond was determined every two weeks to check their growth. Feeding was stopped $24 \mathrm{~h}$ prior to weighing. A volume of $30 \%$ of the fresh water in each pond was renewed through the outlet at the bottom of the ponds daily before feeding. They were provided with continuous aeration to maintain the dissolved oxygen level near saturation, and the fish were held under natural light. Water temperature and dissolved oxygen were measured every other day using a YSI 58 oxygen meter (YSI Company, Yellow Springs Instrument, Yellow Springs, Ohio, USA). Total ammonia and nitrite were measured twice weekly with a DREL 2000 spectrophotometer (Hash Company, Loveland, CO, USA). Total alkalinity and chloride were monitored twice weekly by titration; $\mathrm{pH}$ was monitored twice weekly using a $\mathrm{pH}$ meter (Orion $\mathrm{pH}$ meter, Abilene, Texas, USA). All tested water quality criteria (temperature, $\mathrm{DO}, \mathrm{pH}$, total ammonia and nitrite) were estimated according to standard methods as described elsewhere (Hassaan et al. 2014).

\section{Experimental diets}

Four isonitrogenous and isolipidic diets were formulated (Table 1). Soybean meal contributed the major portion of dietary protein. The proximate composition of the experimental diets was within the desired formulated values with about $300 \mathrm{~g} \mathrm{~kg}^{-1}$ crude protein and 19.45 $\mathrm{MJ} \mathrm{kg}^{-1}$ gross energy. The control diet contained no added yeast extract. Three diets were supplemented with 5, 10, and $15 \mathrm{~g} \mathrm{~kg}^{-1}$ yeast extract per diet, respectively, (Mark Co., Ltd., Tokyo, Japan (CW-I). The final product was in the form of a fine powder, containing nucleotides $\left(104.4 \mathrm{~g} \mathrm{~kg}^{-1}\right)$ and $\beta$-glucan $\left(70.3 \mathrm{~g} \mathrm{~kg}^{-1}\right)$. The ingredients were ground into fine powder through $200 \mu \mathrm{m}$ mesh. The quantities of extract were mixed with $6 \mathrm{ml}$ of distilled water and added to the base ingredient, all the ingredients were thoroughly mixed with soybean oil, and then the mixture was passed through a laboratory pellet mill (2-mm die;

California Pellet Mill, San Francisco, CA, USA) at the National Institute of Oceanography and Fisheries, Cairo Governorate, Egypt, and stored at $-20{ }^{\circ} \mathrm{C}$ until used. 
122 At the end of the feeding trial, $24 \mathrm{~h}$ following the last feeding, all the fish were counted 123 and weighed to determine final body weight (g), weight gain (WG), specific growth rate

$124\left(\mathrm{SGR}, \% \mathrm{day}^{-1}\right)$, feed conversion ratio (FCR), protein efficiency ratio (PER), and feed intake.

125 The growth response parameters were calculated as follows:

126 Weight gain $(\mathrm{WG})=$ final body weight $(\mathrm{g})$ - initial body weight $(\mathrm{g})$

127 Specific growth rate $(\mathrm{SGR})=100 \times(\mathrm{Ln} W 2-\mathrm{Ln} W 1) / \mathrm{T}$

128 Where: $\mathrm{Ln}=$ natural $\log ; \mathrm{W} 1$ = initial body weight; W2 = final body weight and T = study

129 period (84 days). Feed conversion ratio $(\mathrm{FCR})=$ Feed intake $(\mathrm{g}) / \mathrm{WG}(\mathrm{g})$. Protein efficiency

130 ratio $(\mathrm{PER})=\mathrm{WG}(\mathrm{g}) /$ Protein intake $(\mathrm{g})$.

\section{Hematological and biochemical blood analysis}

132 At the end of the experimental trial, ten fish were collected randomly from each of the 133 treatment and control groups. The fish were anesthetized with benzocaine $\left(50 \mathrm{mg} \mathrm{l}^{-1}\right)$ (Sigma-

134 Aldrich) before blood was drawn. Blood samples were collected from the caudal vein of the

135 fish from all treatments and were divided into two portions. The first portion was collected 136 with anticoagulant $10 \%$ EDTA (ethylenediaminetetraacetate) to measure hematocrit (Htc), 137 hemoglobin $(\mathrm{Hb})$, red blood cells (RBCs), and white blood cells (WBCs). Htc was determined 138 and described by (Reitman and Frankel 1957), hemoglobin ( $\mathrm{Hb}$ ) was determined with 139 hemoglobin kits, which is the standard procedure for the cyanomethemoglobin method. RBCs 140 were counted under a light microscope using a Neubauer hemocytometer after blood dilution 141 with phosphate-buffered saline ( $\mathrm{pH} 7.2$ ), the WBCs were determined according to (Barros et 142 al. 2009). The second portion of the blood sample was allowed to clot overnight at $4^{\circ} \mathrm{C}$, and 143 then it was centrifuged at 3,000 rpm for $10 \mathrm{~min}$. Non-hemolyzed serum was collected and 144 stored at $-20{ }^{\circ} \mathrm{C}$ until analysis. Levels of serum aspartate aminotransferase (AST), alanine 145 aminotransferase (ALT) according the method described by Reitman and Frankel (1957), 
146 while serum creatinine was measured with the colorimetric method and enzymatic

147 determination methods and described by (Henary et al. 1974). In addition, serum total protein,

148 albumin, and globulin were determined spectrophotometrically using methods described by

149 Doumas et al. (1981).

$150 \quad$ Histological analysis

151 On day 84 of the experiment, the livers and digestive tract mid-sections of five fish from

152 each treatment were excised carefully and fixed in $10 \%$ formalin, dehydrated in ascending

153 grades of alcohol, and cleared in xylene. The fixed tissues were embedded in paraffin wax,

154 and $5 \mu \mathrm{m}$ sections were cut with a Euromex Holland microtome (Arnhem, The Netherlands).

155 The sections were stained with the Harris hematoxylin and eosin (H\&E) method. Next, these

156 sections were examined microscopically, and photographs were taken with a microscope

157 camera (Bernet et al. 1999).

158 Chemical composition

159 At termination of the trial, a random sample of five individual fish were sampled from each

160 pond, oven-dried at $105{ }^{\circ} \mathrm{C}$ for $24 \mathrm{~h}$, ground, and stored at $-20{ }^{\circ} \mathrm{C}$ for subsequent analysis.

161 Proximate analysis was conducted on both diet and fish samples. Dry matter, total lipids, crude

162 protein, and ash contents were all determined with standard methods (AOAC 1995). Dry matter

163 was determined after drying the samples in an oven $\left(105^{\circ} \mathrm{C}\right)$ for $24 \mathrm{~h}$. Ash was determined by

164 incineration at $550^{\circ} \mathrm{C}$ for $12 \mathrm{~h}$ (AOAC 1995); according to method number 942.05). Crude

165 protein was determined with the micro-Kjeldhal method, $\mathrm{N} \times 6.25$ (using a Kjeltech 1030 auto

166 analyzer, Tecator, Höganäs, Sweden) according to method number 984.13, and crude fat by

167 Soxhlet extraction with diethyl ether (40-60 $\left.{ }^{\circ} \mathrm{C}\right)$ (AOAC 1995); according to method number

168 920.39). Total carbohydrate was computed by subtracting the sum of the crude protein, crude

169 lipid, and ash contents from 100.

170 Statistical analysis 
172 (Statistical Analysis System 2004). The data were submitted to one-way classification

173 variance analysis. Duncan's multiple range test was used to compare differences among

174 treatment means when significant $F$ values were obtained (Duncan 1955) at a level of

175 significance of $\mathrm{P}<0.05$. A linear model was performed with Sigma Plot version 8 (SPSS Inc.

176 Chicago, IL, USA) for the response variable using means \pm SE. All percentage data were arc-

177 sin transformed prior to analysis (Zar 1984); however, the data are presented untransformed to 178 facilitate comparisons.

179 Results

180 Growth parameters

181 The positive water quality criteria were associated with good growth performance 182 since there were no mortalities in any of the treatments throughout the experiment. The 183 growth performance of Oreochromis niloticus fed the experimental diets is presented in Table

184 2. There were no significant differences in initial weights among the treatment groups; 185 however, after 84 days the group fed the diet containing $15 \mathrm{~g} \mathrm{~kg}^{-1}$ yeast extract had the highest 186 final body weights and specific growth rates (SGR). Figure 1 shows that weight gain (WG) 187 increased linearly as dietary supplementation increased. Feed intake in the present study 188 increased significantly with increased levels of yeast extract. Figure 1 showed that the feed 189 conversion ratio (FCR) decreased linearly as dietary supplementation increased. The addition 190 of yeast extract to the feed also produced a better protein efficiency ratio (PER) with values 191 significantly $(\mathrm{p}<0.05)$ higher than those in the control, more specifically in the groups treated 192 with $15 \mathrm{~g} \mathrm{~kg}^{-1}$ yeast extract. There was no significant difference in the final body weight, 193 SGR, or PER between groups 5 and $10 \mathrm{~g} \mathrm{~kg}^{-1}$ yeast extract.

194 Chemical composition of whole fish 
195 According to the body analysis composition data at the end of the experiment, 196 supplementing the feed with yeast extract did not have a significant $(\mathrm{P}>0.05)$ impact on dry 197 matter, lipid, crude protein, or ash contents of the fish (Table 3).

\section{Hematological parameters}

199 Table 4 shows the effect of yeast extract on Nile tilapia hematological indexes including 200 hematocrit $(\mathrm{Htc})$, hemoglobin $(\mathrm{Hb})$, and the red blood cell $(\mathrm{RBC})$, and white blood cell

201 (WBC) counts. No significant differences were noted in Hct or Hb levels among all the 202 treatments. RBC and WBC counts were significantly $(\mathrm{P}<0.05)$ higher in the fish fed the 203 highest level of yeast extract $\left(15 \mathrm{~g} \mathrm{~kg}^{-1}\right.$ diet $)$ in comparison with other treatment groups.

204 Biochemical blood parameters

205 According to the results of the analysis, the fish that received the highest concentration of 206 yeast extract $(15 \mathrm{~g})$ in their diets exhibited significantly $(\mathrm{P}<0.05)$ lower AST and ALT activity 207 in comparison with the values noted in the other treatments (Table 5). No significant $(\mathrm{P}>$ 208 0.05) differences were noted in the total protein levels in any of the treatments. Fish fed diets 209 containing 10 and $15 \mathrm{~g} \mathrm{~kg}^{-1}$ yeast extract had significantly higher albumin and globulin levels 210 than did the fish fed control diet (Table 5). Some of the other recorded parameters, such as 211 cholesterol and triglyceride levels, in the fish supplemented with yeast extract were

212 significantly lower $(\mathrm{P}<0.05)$ than those in the control group. The lowest cholesterol and

213 triglyceride levels were recorded in fish fed diets with $15 \mathrm{~g} \mathrm{~kg}^{-1}$ yeast extract (Table 5).

\section{Histology}

215 The liver and intestine histology of Nile tilapia fed diets with control and/or different 216 levels of yeast extract are illustrated in Figure 2. The histological changes in fish liver and 217 intestines were assessed with light microscopy, which revealed that the fish fed the control 218 diet exhibited some changes in these organs. Changes in the liver included degeneration and 219 necrosis in the hepatocytes with congestion in the blood sinusoids of fish fed control diet 
(Figure 2a), while the intestine showed degeneration in mucosa and necrosis in submucosa layers in

221 fish fed the control diet (Figure 2c). Fish fed diet supplemented with (10 or $\left.15 \mathrm{~g} \mathrm{~kg}^{-1}\right)$ exhibited an

222 almost normal hepatocyte structure (Figure 2b) and intestinal layers (Figure 2d).

\section{$223 \quad$ Discussion}

224 The diet supplemented with high levels of yeast extract $\left(15 \mathrm{~g} \mathrm{~kg}^{-1}\right)$ increased the growth 225 rate and feed utilization of Nile tilapia. The yeast extract used in the present study contained 226 nucleotides $\left(10.44 \mathrm{~g} \mathrm{~kg}^{-1}\right)$ and $\beta$-glucan $\left(70.3 \mathrm{~g} \mathrm{~kg}^{-1}\right)$, which facilitated fish growth (Carver 227 1994). Supplemented diets with $0.1 \% \beta$-glucan improved Nile tilapia weight gain (Welker et 228 al. 2012). Diets containing $\beta$-glucan and mannan oligosaccharides (MOS) have also previously been found to improve the growth performance of Nile tilapia and Beluga, Huso Huso (Abdel-Tawwab et al. 2008, Selim and Reda 2015, Ta'ati et al. 2011). In our experiment,

231 feed intake increased significantly with increasing levels of Saccharomyces cerevisiae extract 232 in the diet. This could have been because the extract nucleotide content of adenosine 233 monophosphate, inosine monophosphate, uridine monophosphate, and adenosine diphosphate 234 are proven palatability enhancers and feed attractants ( $\mathrm{Li}$ and Gatlin 2006, Oliva-Teles et al. 235 2006). Furthermore, dietary nucleotide supplementation has also been shown to enhance 236 growth in other fish species such as Atlantic salmon (Burrells et al. 2001), grouper, 237 Epinephelus malabaricus (Lin et al. 2009) and rainbow trout, Oncorhynchus mykiss 238 (Tahmasebi-Kohyani et al. 2011). However, JarmoŁowicz et al. (2012) reported that 239 supplementing diets with yeast extract $\left(\mathrm{NuPro}^{\circledR}\right)$ did not significantly impact the growth rates 240 of juvenile European pikeperch, Sander lucioperca. The reasons for the differences among 241 these studies could stem from the differences in species, physiological conditions, and the 242 type of basal ingredients in the diets.

243 No significant $(\mathrm{P}>0.05)$ differences were noted in the analysis of the proximate 244 composition of Nile tilapia fed the experimental diets. JarmoŁowicz et al. (2012) observed 
245 that brewer's yeast extract supplementation did not interfere with the metabolism or 246 deposition of nutrients in juvenile pikeperch tissues. The present data was confirmed by the 247 observations of Peres and Oliva-Teles (2003), who supplemented fish diets with nucleotides. 248 Lunger et al. (2006) noted that increasing levels of Saccharomyces cerevisiae extract did not 249 affect nutrient deposition in Nile tilapia. On the other hand, Ebrahimi et al.(2012) 250 demonstrated that a combination of $\beta$-glucan and MOS added to diets in the amount of $2.5 \mathrm{~g}$ $251 \mathrm{~kg}^{-1}$ improved the crude protein content in common carp fingerlings.

252 No significant differences in hemoglobin or hematocrit levels were observed among the 253 fish groups fed diets with yeast extract. Similarly, yeast RNA supplementation had no effect 254 on hematological values of Labeo rohita or Catla catla Choudhury et al. (2005) and Jha et al. 255 (2007). Brewer's yeast extract in doses of $15 \mathrm{~g} \mathrm{~kg}^{-1}$ diet significantly enhanced the WBC 256 count in Nile tilapia blood, which concurs with the study by (Jha et al. 2007), who found that 257 there was an increase in leukocyte count when C. catla fingerlings were treated with 258 nucleotides. Dietary yeast extract activated other functions of carp leucocytes, including 259 phagocytosis that resulted in an increased phagocytic index value (Biswas et al. 2012). Other 260 research has also shown that exogenous nucleotides can influence both the humoral and 261 cellular components of the innate immune system of common carp (Sakai et al. 2001) and 262 hybrid striped bass (Li et al. 2004). The dietary yeast extract used in the present study caused 263 elevated albumin and globulin levels in serum. Albumin and globulin are essential for a 264 healthy immune system (Tahmasebi-Kohyani et al. 2011). The tilapia diet yeast extract 265 supplement elevated the serum albumin and globulin contents in Nile tilapia. The highest 266 globulin values were noted in C. catla fed diets supplemented with yeast RNA, and an 267 increasing trend was noted along with increases in nucleotides (Jha et al. 2007). On the other 268 hand, El-Boshy et al. (2010) noted a significant increase in cellular and humoral immunity in 269 Nile tilapia that received $\beta$-glucan at $0.1 \%$ of the diet for three weeks. In contrast, (Barros et 
al. 2013) proved that plasma total protein, globulin, and albumin in Nile tilapia were not

271 affected by nucleotide levels. JarmoŁowicz et al. (2012) also reported that dietary yeast

272 extract had no significant effect on total protein in juvenile pikeperch.

273 ALT and AST transaminases are important liver enzyme indicators of liver health that 274 control the transfer of amino groups from alpha-amino acids to alpha-keto acids. Thus, high 275 levels of ALT and AST are mostly released into the blood when there is liver cell damage 276 Racicot et al. (1975). In the present study, lower levels of AST and ALT were noted in fish 277 fed diets supplemented with the highest amount of yeast extract $\left(15 \mathrm{~g} \mathrm{~kg}^{-1}\right)$, which might 278 indicate improved liver function (Metwally 2009). Similarly, juvenile pikeperch that received yeast extract (40 and $60 \mathrm{~g} \mathrm{~kg}^{-1}$ diet) in their diets exhibited significantly lower AST and ALT 280 activity in comparison with the control group Jarmołowicz et al. (2012). Histological 281 analysis corresponded with the lower liver transaminases noted in the groups that received 15 $282 \mathrm{~g} \mathrm{~kg}^{-1}$ yeast extract, which might also indicate improved liver function. Microcopy 283 observations revealed there was little liver or intestine damage after yeast extract diet 284 supplementation. Meanwhile, in other analyzed variants (even in the control group) 285 significant damage was noted in these organs including degeneration, necrosis in hepatocytes, 286 and degeneration in the hypodermis layer and villi, which often occurs after feeding of high 287 soybean diets or in intensive fish farming conditions. A histological analysis of the liver of 288 sea bass fed different levels of yeast extract showed steatosis with fat degeneration, while 289 liver morphology was considerably improved with yeast extract supplementation 290 (Panagiotidou et al. 2009). Moreover, nucleotide supplementation significantly increased 291 distal intestine fold height, enterocyte height, and microvillus height in juvenile turbot, 292 Scophthalmus maximus, compared to the control diet (Peng et al. 2013). In turn, Cheng et al. 293 (2011) noted that dietary nucleotide supplementation significantly improved intestinal 294 structure in red drum. JarmoŁowicz et al. (2012) reported that changes in intestinal 
morphology result in greater cell absorption activity and better digestion of nutrients in the

296 intestine, which usually leads to improved growth performance and feed utilization. The

297 beneficial effects of dietary nucleotides on hepatocytes and the gastrointestinal tract have

298 been more widely investigated in mammals, and nucleotides have been found to improve

299 hepatic function and to promote earlier restoration of nitrogen balance following liver injury

300 (reviewed by (Sauer et al. 2009). Dietary nucleotides have also been noted to repair intestinal

301 mucosa after chronic diarrhea induced by a lactose enriched diet in weanling rats fed AMP,

302 GMP, IMP, CMP, and UMP (50 mg $100 \mathrm{~g}^{-1} \mathrm{each}$ ) (Bueno et al. 1994). Nucleotides are partly

303 absorbed in the gut as nucleosides trough active transport and $\mathrm{Na}^{+}$cotransport and

304 incorporated into body tissues, mainly the liver, spleen, bone marrow, and gut (Bueno et al.

305 1994). Dietary sources of nucleotides might be conditionally essential nutrients. Rapidly

306 growing tissues such as intestinal epithelium or lymphoid cells lack significant capacity for de

307 novo synthesis of nucleotides and require exogenous sources of purine and pyrimidine bases

308 (Uauy et al. 1994).

309 The present study is the first report on the triglyceride and cholesterol parameters of Nile

310 tilapia fed diets supplemented with yeast extract, and these levels were significantly lower in

311 comparison with the control group. In another 8-week study rainbow trout fed a diet

312 supplemented with $1-2 \mathrm{~g} \mathrm{~kg}^{-1}$ nucleotides exhibited significant decreases in low-density

313 lipoprotein (LDL)-C and triglycerides in comparison with the control fish (Mohebbi et al.

314 2013). In recent years, dietary nucleotides have been shown to influence lipid metabolism and

315 fatty acids, but the mechanisms by which dietary nucleotides affect circulatory lipids

316 concentrations are not clear. Some researchers believe that dietary nucleotides might increase

317 the synthesis of long-chain polyunsaturated fatty acids possibly by influencing the activity of

318 intestinal and hepatic desaturase enzymes (Gil et al. 1988). For example, feeding a 
319 nucleotide-supplemented diet resulted in a significant increase in plasma polyunsaturated fatty

320 acids in mammals (Gil et al. 1986, Boza et al. 1992, Jiménez et al. 1992).

321 Generally, brewer's yeast is a particularly important natural bio-product since it contains

322 immune-stimulating compounds such as $\beta$-glucan, nucleotides, mannan oligosaccharides, and

323 chitin, and it has been proven to influence the immune response (Abdel-Tawwab 2012, Li et

324 al. 2004, Bidhan 2011). The results of our study indicate that the diets supplemented with

325 yeast extract improved growth, and have beneficial effects on hematological and biochemical

326 blood parameters, lipid profiles, and the histological structure of liver and gut of Nile tilapia.

327 It can also be used as a source of nucleotides and $\beta$-glucan.

328 Acknowledgments

329 The authors are grateful to the Fish Nutrition Laboratory, National Institute of

330 Oceanography and Fisheries, Egypt (NIOF) and the faculty of Agriculture, Benha, University,

331 Egypt for providing their technical facilities.

332 


\section{References}

334 Abdel-Tawwab M, Abdel-Rahman A.M, Ismael N.E.M. 2008. Evaluation of commercial live baker's

335 yeast, Saccharomyces cerevisiae as a growth and immunity promoter for fry Nile tilapia,

336 Oreochromis niloticus (L.) challenged in situ with Aeromonas hydrophila. Aquaculture, 280, $337 \quad 185-189$.

338 Abdel-Tawwab, M. 2012. Interactive effects of dietary protein and live bakery yeast, Saccharomyces 339 cerevisiae on growth performance of Nile tilapia, Oreochromis niloticus (L.) fry and their

AOAC 1995. In: Cunni, P.A. (Ed.), Official Methods of Analysis of the Association Official

Barros, M. M., Guimarães, I. G., Pezzato, L. E., Oliveira Orsi, R., Fernandes Junior, A. C., Teixeira, C. P., Fleuri, L. F. \& Padovani, C. R. 2013. The effects of dietary nucleotide mixture on growth performance, haematological and immunological parameters of Nile tilapia. Aquaculture

Barros, M. M., Ranzani-Paiva, M. J. T., Pezzato, L. E., Falcon, D. R. \& Guimaraes, I. G. 2009. Haematological response and growth performance of Nile tilapia (Oreochromis niloticus L.) fed diets containing folic acid. Aquaculture Research, 40, 895-903.

Bekatorou, A., Psarianos, C. \& Koutinas, A. A. 2006. Production of food grade yeasts. Food

Bernet, D., Schmidt, H., Meier, W., Burkhardt-Holm, P. \& Wahli, T. 1999. Histopathology in fish: proposal for a protocol to assess aquatic pollution. Journal of Fish Diseases, 22, 25-34.

Bidhan, C. P. 2011. Oral administration of baker's yeast (Saccharomyces cerevisiae) acts as a growth promoter and immunomodulator in Labeo rohita (Ham.). Journal of Aquaculture Research \& Development.

Biswas, G., Korenaga, H., Takayama, H., Kono, T., Shimokawa, H. \& Sakai, M. 2012. Cytokine responses in the common carp, Cyprinus carpio L. treated with baker's yeast extract. Aquaculture, 356, 169-175. 
Boza, J., Jimenez, J., Faus, M. J. \& Gil, A. 1992. Influences of postnatal age and dietary nucleotides on plasma fatty acids in the weanling rat. Journal of Parenteral and Enteral Nutrition, 16, 322326.

363

364

Bueno, J., Torres, M., Almendros, A., Carmona, R., Nunez, M., Rios, A. \& Gil, A. 1994. Effect of dietary nucleotides on small intestinal repair after diarrhoea. Histological and ultrastructural changes. Gut, 35, 926-933.

Burrells, C., Williams, P. \& Forno, P. 2001. Dietary nucleotides: a novel supplement in fish feeds: 1. Effects on resistance to disease in salmonids. Aquaculture, 199, 159-169.

Carver, J. D. 1994. Dietary nucleotides: cellular immune, intestinal and hepatic system effects. The Journal of nutrition, 124,144 S-148S.

Carver, J. D. \& Walker, W. A. 1995. The role of nucleotides in human nutrition. The Journal of Nutritional Biochemistry, 6, 58-72.

Cheng, Z., Buentello, A. \& Gatlin, D. M. 2011. Dietary nucleotides influence immune responses and intestinal morphology of red drum Sciaenops ocellatus. Fish \& Shellfish Immunology, 30, 143147.

Choudhury, D., Pal, A., Sahu, N., Kumar, S., Das, S. \& Mukherjee, S. 2005. Dietary yeast RNA supplementation reduces mortality by Aeromonas hydrophila in rohu (Labeo rohita L.) juveniles. Fish \& Shellfish Immunology, 19, 281-291.

Couso, N., Castro, R., Magariños, B., Obach, A. \& Lamas, J. 2003. Effect of oral administration of glucans on the resistance of gilthead seabream to pasteurellosis. Aquaculture, 219, 99-109.

Ebrahimi, G., Ouraji, H., Khalesi, M., Sudagar, M., Barari, A., Zarei Dangesaraki, M. \& Jani Khalili, K. 2012. Effects of a prebiotic, Immunogen ${ }^{\circledR}$, on feed utilization, body composition, immunity and resistance to Aeromonas hydrophila infection in the common carp Cyprinus carpio (Linnaeus) fingerlings. Journal of animal physiology and animal nutrition, 96, 591-599.

El-Boshy, M. E., Ahmed, M., AbdelHamid, F. M. \& Gadalla, H. A. 2010. Immunomodulatory effect of dietary Saccharomyces cerevisiae, $\beta$-glucan and laminaran in mercuric chloride treated Nile tilapia (Oreochromis niloticus) and experimentally infected with Aeromonas hydrophila. Fish \& Shellfish Immunology, 28, 802-808. 
388 Ferreira, I., Pinho, O., Vieira, E. \& Tavarela, J. 2010. Brewer's Saccharomyces yeast biomass: 389 characteristics and potential applications. Trends in food science \& technology, 21, 77-84.

390 Gil, A., Lozano, E., De-Lucchi, C., Maldonado, J., Molina, J. \& Pita, M. 1988. Changes in the fatty 391 acid profiles of plasma lipid fractions induced by dietary nucleotides in infants born at term. 392 European journal of clinical nutrition, 42, 473-481.

393 Gil, A., Pita, M., Martinez, A., Molina, J. \& Sánchez, M. F. 1986. Effect of dietary nucleotides on the 394 plasma fatty acids in at-term neonates. Human nutrition. Clinical nutrition, 40, 185-195.

395 Hassaan, M. S., Goda, A. M. A., Mahmoud, S. A. \& Tayel, S. I. 2014. Protective effect of dietary 396 vitamin E against fungicide copperoxychloride stress on Nile tilapia, Oreochromis niloticus 397 (L.), fingerlings. International Aquatic Research, 6, 1.

398 Henary, R., Cannon, D. \& Winkleman, J. 1974. Clinical chemistry principles and techniques. Harper 399 and Roe, New York.

400 JarmoŁowicz, S., ZakĘŚ, Z., Siwicki, A., Kowalska, A., Hopko, M., GŁĄbski, E., 401 DEMSKA-ZAKĘŚ, K. \& Partyka, K. 2012. Effects of brewer's yeast extract on growth 402 performance and health of juvenile pikeperch Sander lucioperca (L.). Aquaculture Nutrition, 18, $403 \quad 457-464$.

404 Jha, A. K., Pal, A., Sahu, N., Kumar, S. \& Mukherjee, S. 2007. Haemato-immunological responses to 405 dietary yeast RNA, $\omega-3$ fatty acid and $\beta$-carotene in Catla catla juveniles. Fish \& Shellfish $406 \quad$ Immunology, 23, 917-927.

407 Jiménez, J., Boza Jr, J., Suárez, M. D. \& Gil, A. 1992. Changes in fatty acid profiles of red blood cell 408 membranes mediated by dietary nucleotides in weanling rats. Journal of pediatric gastroenterology and nutrition, 14, 293-299.

413 Aquaculture Research, 36, 1120-1127. 
414 Li, P. \& Gatlin, D. M. 2004. Dietary brewers yeast and the prebiotic Grobiotic ${ }^{\mathrm{TM}}$ AE influence growth 415 performance, immune responses and resistance of hybrid striped bass (Morone chrysops $\times$ M. 416 saxatilis) to Streptococcus iniae infection. Aquaculture, 231, 445-456.

417 Li, P. \& Gatlin, D. M. 2006. Nucleotide nutrition in fish: current knowledge and future applications. $418 \quad$ Aquaculture, 251, 141-152.

419 Li, P., Lewis, D. H. \& Gatlin, D. M. 2004. Dietary oligonucleotides from yeast RNA influence 420 immune responses and resistance of hybrid striped bass (Morone chrysops $\times$ Morone saxatilis) to 421 Streptococcus iniae infection. Fish \& Shellfish Immunology, 16, 561-569.

422 Lin, Y. H., Wang, H. \& Shiau, S. Y. 2009. Dietary nucleotide supplementation enhances growth and 423 immune responses of grouper, Epinephelus malabaricus. Aquaculture Nutrition, 15, 117-122.

424 Lunger, A. N., Craig, S. \& McLean, E. 2006. Replacement of fish meal in cobia (Rachycentron 425 canadum) diets using an organically certified protein. Aquaculture, 257, 393-399.

426 Metwally, M. 2009. Effects of garlic (Allium sativum) on some antioxidant activities in tilapia nilotica 427 (Oreochromis niloticus). World Journal of Fish and Marine Sciences, 1, 56-64.

428 Mohebbi, A., Nematollahi, A., Gholamhoseini, A., Tahmasebi-Kohyani, A. \& Keyvanshokooh, S. 429 2013. Effects of dietary nucleotides on the antioxidant status and serum lipids of rainbow trout $430 \quad$ (Oncorhynchus mykiss). Aquaculture Nutrition, 19, 506-514.

431 Nguyen, T., Fleet, G. \& Rogers, P. 1998. Composition of the cell walls of several yeast species. 432 Applied microbiology and biotechnology, 50, 206-212.

433 Oliva-Teles, A., Guedes, M., Vachot, C. \& Kaushik, S. 2006. The effect of nucleic acids on growth, 434 ureagenesis and nitrogen excretion of gilthead sea bream Sparus aurata juveniles. Aquaculture, $435 \quad 253,608-617$.

436 Panagiotidou, M., Nengas, I., Henry, M., Rigos, G., Charalambous, C. \& Sweetman, J. 2009. EffEct of 437 diffErEnt diEtary 1 EvEls of yEast Extract (nupro® on growth, fEEd utilisation and immunE 438 systEm of sEa bass (dicEntrarchus labrax). 
Peng, M., Xu, W., Ai, Q., Mai, K., Liufu, Z. \& Zhang, K. 2013. Effects of nucleotide supplementation on growth, immune responses and intestinal morphology in juvenile turbot fed diets with graded levels of soybean meal (Scophthalmus maximus L.). Aquaculture, 392, 51-58.

Peres, H. \& Oliva-Teles, A. 2003. The effect of dietary ribonucleic acid incorporation in performance of European sea bass (Dicentrarchus labrax) juveniles. Aquaculture, 215, 245-253.

Quan, R. 1992. Dietary nucleotides: potential for immune enhancement. Foods, nutrition and Immunity, 1, 13-21.

Racicot, J., Gaudet, M. \& Leray, C. 1975. Blood and liver enzymes in rainbow trout (Salmo gairdneri Rich.) with emphasis on their diagnostic use: Study of CCl4 toxicity and a case of Aeromonas infection. Journal of fish Biology, 7, 825-835.

Reitman, S. \& Frankel, S. 1957. A colorimetric method for the determination of serum glutamic oxalacetic and glutamic pyruvic transaminases. American journal of clinical pathology, 28, 56 .

Sakai, M., Taniguchi, K., Mamoto, K., Ogawa, H. \& Tabata, M. 2001. Immunostimulant effects of nucleotide isolated from yeast RNA on carp, Cyprinus carpio L. Journal of Fish Diseases, 24,

Sauer, N., Bauer, E. \& Mosentih, R. 2009. Dietary nucleotides: potential contenders as feed additive

Selim, K. M. \& Reda, R. M. 2015. Beta-Glucans and Mannan Oligosaccharides Enhance Growth and Immunity in Nile Tilapia. North American Journal of Aquaculture, 77, 22-30.

Ta'ati, R., Soltani, M., Bahmani, M. \& Zamini, A. 2011. Effects of the prebiotics Immunoster and Immunowall on growth performance of juvenile beluga (Huso huso). Journal of Applied 467 
Tahmasebi-Kohyani, A., Keyvanshokooh, S., Nematollahi, A., Mahmoudi, N. \& Pasha-Zanoosi, H. 2011. Dietary administration of nucleotides to enhance growth, humoral immune responses, and disease resistance of the rainbow trout (Oncorhynchus mykiss) fingerlings. Fish \& Shellfish Immunology, 30, 189-193.

473 Torrecillas, S., Makol, A., Caballero, M., Montero, D., Robaina, L., Real, F., Sweetman, J., Tort, L. \&

474 Izquierdo, M. 2007. Immune stimulation and improved infection resistance in European sea 475 bass (Dicentrarchus labrax) fed mannan oligosaccharides. Fish \& Shellfish Immunology, 23, $476969-981$.

477 Uauy, R., Quan, R. \& Gil, A. 1994. Role of Nucleotides in Intestinal Development and 478 Repair: 480 Implications for Infant Nutrition. The Journal of nutrition, 124, 1436S$479 \quad$ 1441S.

480 Welker, T. L., Lim, C., Yildirim-Aksoy, M. \& Klesius, P. H. 2012. Use of Diet Crossover to 481 Determine the Effects of $\beta$-glucan Supplementation on Immunity and Growth of Nile Tilapia, 482 Oreochromis niloticus. Journal of the World Aquaculture Society, 43, 335-348.

483 Zar, J. 1984. Multiple comparisons. Biostatistical analysis, 1, 185-205.

484

485 
TABLE 1 Composition and proximate analysis of the basal diet ( $\mathrm{g} \mathrm{kg}^{-1}$ dry matter)

\begin{tabular}{lcccc}
\hline Ingredients & Control & $\begin{array}{c}5 \mathrm{~g} \mathrm{~kg}^{-1} \\
\text { yeast extract }\end{array}$ & $\begin{array}{c}10 \mathrm{~g} \mathrm{~kg}^{-1} \\
\text { yeast extract }\end{array}$ & $\begin{array}{c}15 \mathrm{~g} \mathrm{~kg}^{-1} \\
\text { yeast extract }\end{array}$ \\
\hline Fish meal & 100 & 100 & 100 & 100 \\
Soybean meal & 460 & 460 & 460 & 460 \\
Yellow corn & 295 & 295 & 295 & 295 \\
Wheat bran & 100 & 95 & 90 & 85 \\
soybean oil & 30 & 30 & 30 & 30 \\
Vitamins and minerals & & 15 & 15 & 15 \\
Yeast extract $(\mathrm{CW}-\mathrm{I})$ & 15 & 5 & 10 & 15 \\
Proximate analysis $\left(\mathrm{g} \mathrm{kg}^{-1}\right.$ dry matter basis) & 0 & & & \\
Crude protein & 300.50 & 298.80 & 298.00 & 297.30 \\
Lipids & 56.91 & 57.20 & 56.71 & 57.21 \\
Ash & 54.30 & 54.12 & 53.81 & 53.21 \\
Total carbohydrate & & 589.88 & 591.84 & 592.28 \\
Gross energy $\left(\mathrm{MJ} \mathrm{kg}^{-1}\right)^{3}$ & 5883 & 19.44 & 19.42 & 19.43 \\
\hline \multicolumn{1}{l}{${ }^{2}$ Vitams } & 19.45 & & & \\
\hline
\end{tabular}

${ }^{1}$ Vitamins and minerals mix: MnSO4, $40 \mathrm{mg}$; MgO, $10 \mathrm{mg}$; K2SO4, $40 \mathrm{mg}$; ZnCO3, $60 \mathrm{mg}$; KI, $0.4 \mathrm{mg}$; CuSO4, $12 \mathrm{mg}$; Ferric citrate, $250 \mathrm{mg}$; Na2SeO3, $0.24 \mathrm{mg}$; Co, $0.2 \mathrm{mg}$; retinol, $40000 \mathrm{IU}$; cholecalciferol, $4000 \mathrm{IU}$; $\alpha$-tocopherolacetate, $400 \mathrm{mg}$; menadione, $12 \mathrm{mg}$; thiamine, $30 \mathrm{mg}$; riboflavin, $40 \mathrm{mg}$; pyridoxine, $30 \mathrm{mg}$; cyanocobalamin, $80 \mathrm{mcg}$; ;nicotinic acid, $300 \mathrm{mg}$; folic acid, $10 \mathrm{mg}$; biotin, $3 \mathrm{mg}$; pantothenic acid, $100 \mathrm{mg}$; inositol, $500 \mathrm{mg}$; ascorbic acid, $500 \mathrm{mg}$.

${ }^{2}$ Total carbohydrate $=100$-(crude protein + lipid + ash).

${ }^{3}$ Calculated using gross calorific values of $23.63,39.52$ and $17.15 \mathrm{KJ} / \mathrm{g}$ for protein, fat and carbohydrate, respectively according to (Brett 1973) 
TABLE 2 Growth indices and nutrient utilization of O. niloticus after 84 days of feeding yeast extract supplemented diets

\begin{tabular}{lccccc}
\hline Items & Control & $\begin{array}{c}5 \mathrm{~g} \mathrm{~kg}^{-1} \\
\text { yeast extract }\end{array}$ & $\begin{array}{c}10 \mathrm{~g} \mathrm{~kg}^{-1} \\
\text { yeast extract }\end{array}$ & $\begin{array}{c}15 \mathrm{~g} \mathrm{~kg}^{-1} \\
\text { yeast extract }\end{array}$ & P value \\
\hline Initial body weight $\left(\mathrm{g} \mathrm{fish}^{-1}\right)$ & $5.89 \pm 0.56$ & $5.84 \pm 0.49$ & $5.84 \pm 0.54$ & $5.87 \pm 0.45$ & 0.875 \\
Final body weight $\left(\mathrm{g} \mathrm{fish}^{-1}\right)$ & $34.40 \pm 1.56^{\mathrm{c}}$ & $40.12 \pm 1.71^{\mathrm{b}}$ & $40.45 \pm 1.15^{\mathrm{b}}$ & $42.99 \pm 1.78^{\mathrm{a}}$ & 0.014 \\
Specific growth rate $(\%$ per day) & $1.95 \pm 0.12^{\mathrm{c}}$ & $2.12 \pm 0.11^{\mathrm{b}}$ & $2.13 \pm 0.09^{\mathrm{b}}$ & $2.31 \pm 0.13^{\mathrm{a}}$ & 0.012 \\
Feed intake $\left(\mathrm{g} \mathrm{fish}{ }^{-1}\right)$ & $52.88 \pm 1.13^{\mathrm{c}}$ & $54.78 \pm 1.88^{\mathrm{b}}$ & $55.39 \pm 1.90^{\mathrm{b}}$ & $56.33 \pm 1.18^{\mathrm{a}}$ & 0.023 \\
Protein efficiency ratio & $1.82 \pm 013^{\mathrm{c}}$ & $2.12 \pm 011^{\mathrm{b}}$ & $2.12 \pm 013^{\mathrm{b}}$ & $2.23 \pm 0.12^{\mathrm{a}}$ & 0.017
\end{tabular}

Results were presented as means \pm SE of triplicate observations. Means in the same row with different superscript letters were significantly different $(\mathrm{p}<0.05)$. 
TABLE 3 Chemical composition of $O$. niloticus after 84 days of feeding yeast extract supplemented diets ( $\mathrm{g} \mathrm{kg}^{-1}$ wet basis)

\begin{tabular}{lccccc}
\hline Items & Control & $\begin{array}{c}5 \mathrm{~g} \mathrm{~kg}^{-1} \\
\text { yeast extract }\end{array}$ & $\begin{array}{c}10 \mathrm{~g} \mathrm{~kg}^{-1} \\
\text { yeast extract }\end{array}$ & $\begin{array}{c}15 \mathrm{~g} \mathrm{~kg}^{-1} \\
\text { yeast extract }\end{array}$ & P value \\
\hline Dry matter & $272.17 \pm 1.89$ & $277.02 \pm 2.01$ & $278.34 \pm 1.87$ & $279.46 \pm 2.10$ & 0.084 \\
Crude protein & $158.25 \pm 1.23$ & $159.21 \pm 1.52$ & $159.98 \pm 2.11$ & $162.02 \pm 1.15$ & 0.781 \\
Lipid & $63.23 \pm 1.00$ & $65.89 \pm 1.17$ & $65.23 \pm 1.12$ & $67.24 \pm 1.12$ & 0.332 \\
Ash & $31.22 \pm 1.12$ & $31.98 \pm 0.98$ & $32.10 \pm 0.90$ & $33.02 \pm 0.91$ & 0.416
\end{tabular}

Results were presented as means \pm SE of triplicate observations. Means in the same row with different superscript letters were significantly different $(p<0.05)$. 
TABLE 4 Hematological parameters of $O$. niloticus after 84 days of feeding yeast extract supplemented diets

\begin{tabular}{lccccc}
\hline Items & Control & $\begin{array}{c}5 \mathrm{~g} \mathrm{~kg}^{-1} \\
\text { yeast extract }\end{array}$ & $\begin{array}{c}10 \mathrm{~g} \mathrm{~kg}^{-1} \\
\text { yeast extract }\end{array}$ & $\begin{array}{c}15 \mathrm{~g} \mathrm{~kg}^{-1} \\
\text { yeast extract }\end{array}$ & P value \\
\hline Hematocrit $(\%)$ & $14.57 \pm 0.89$ & $14.27 \pm 0.99$ & $14.68 \pm 0.79$ & $14.80 \pm 0.78$ & 0.780 \\
Hemoglobin $\left(\mathrm{g} \mathrm{dl}^{-1}\right)$ & $10.31 \pm 0.65$ & $10.45 \pm 0.50$ & $10.65 \pm 0.52$ & $11.00 \pm 0.46$ & 0.452 \\
WBCs $\left(\times 10^{-3} \mathrm{~mm}^{-3}\right)^{1}$ & $35.67 \pm 0.95^{\mathrm{d}}$ & $37.00 \pm 0.87^{\mathrm{c}}$ & $38.33 \pm 1.01^{\mathrm{b}}$ & $40.00 \pm 1.00^{\mathrm{a}}$ & 0.018 \\
RBCs $\left(\times 10^{-3} \mathrm{~mm}^{-3}\right)^{2}$ & $1.81 \pm 0.26^{\mathrm{b}}$ & $1.83 \pm 0.26^{\mathrm{b}}$ & $1.85 \pm 0.16^{\mathrm{b}}$ & $1.91 \pm 0.11^{\mathrm{a}}$ & 0.007 \\
\hline
\end{tabular}

Results were presented as means \pm SE of triplicate observations. Means in the same row with different superscript letters were significantly different $(\mathrm{p}<0.05) .{ }^{1}(\mathrm{WBCs})=$ white blood cell count, ${ }^{2}(\mathrm{RBCs})=$ red blood cell count. 
TABLE 5 Biochemical blood parameters of $O$. niloticus after 84 days of feeding yeast extract supplemented diets

\begin{tabular}{lccccc}
\hline Items & Control & $\begin{array}{c}5 \mathrm{~g} \mathrm{~kg}^{-1} \\
\text { yeast extract }\end{array}$ & $\begin{array}{c}10 \mathrm{~g} \mathrm{~kg}^{-1} \\
\text { yeast extract }\end{array}$ & $\begin{array}{c}15 \mathrm{~g} \mathrm{~kg}^{-1} \\
\text { yeast extract }\end{array}$ & P value \\
\hline ALT $\left(\mathrm{U} \mathrm{l}^{-1}\right)^{1}$ & $90.33 \pm 2.18^{\mathrm{a}}$ & $87.33 \pm 2.14^{\mathrm{b}}$ & $85.30 \pm 2.56^{\mathrm{c}}$ & $84.66 \pm 2.16^{\mathrm{c}}$ & 0.043 \\
AST $\left(\mathrm{U} \mathrm{l}^{-1}\right)^{2}$ & $17.63 \pm 0.56^{\mathrm{a}}$ & $16.83 \pm 0.35^{\mathrm{b}}$ & $15.87 \pm 0.58^{\mathrm{c}}$ & $15.83 \pm 0.45^{\mathrm{c}}$ & 0.0 .32 \\
Total protein $\left(\mathrm{g} \mathrm{dl}^{-1}\right)$ & $3.10 \pm 0.41$ & $3.47 \pm 0.35$ & $3.67 \pm 0.43$ & $3.88 \pm 0.55$ & 0.781 \\
Albumin $\left(\mathrm{g} \mathrm{dl}^{-1}\right)$ & $1.20 \pm 0.11^{\mathrm{b}}$ & $1.28 \pm 0.10^{\mathrm{b}}$ & $1.42 \pm 0.09^{\mathrm{a}}$ & $1.59 \pm 0.12^{\mathrm{a}}$ & 0.034 \\
Globulin $\left(\mathrm{g} \mathrm{dl}^{-1}\right)$ & $1.90 \pm 0.18^{\mathrm{b}}$ & $2.19 \pm 0.13^{\mathrm{b}}$ & $2.25 \pm 0.12^{\mathrm{a}}$ & $2.29 \pm 0.14^{\mathrm{a}}$ & 0.012 \\
Cholesterol $\left(\mathrm{mg} \mathrm{dl}^{-1}\right)$ & $95.00 \pm 3.13^{\mathrm{a}}$ & $82.30 \pm 2.17^{\mathrm{b}}$ & $82.33 \pm 2.59^{\mathrm{b}}$ & $79.32 \pm 2.22^{\mathrm{c}}$ & 0.011 \\
Triglycerides $\left(\mathrm{mg} \mathrm{dl}^{-1}\right)$ & $97.67 \pm 2.98^{\mathrm{a}}$ & $87.33 \pm 3.13^{\mathrm{b}}$ & $82.30 \pm 2.18^{\mathrm{b}}$ & $78.33 \pm 2.13^{\mathrm{c}}$ & 0.012 \\
\hline
\end{tabular}

Results were presented as means \pm MSE of triplicate observations. Means in the same row with different superscript letters were significantly different $(\mathrm{p}<0.05)$.

${ }^{1}(\mathrm{ALT})=$ Alanine aminotransferase,${ }^{2}(\mathrm{AST})=$ Aspartate aminotransferase 


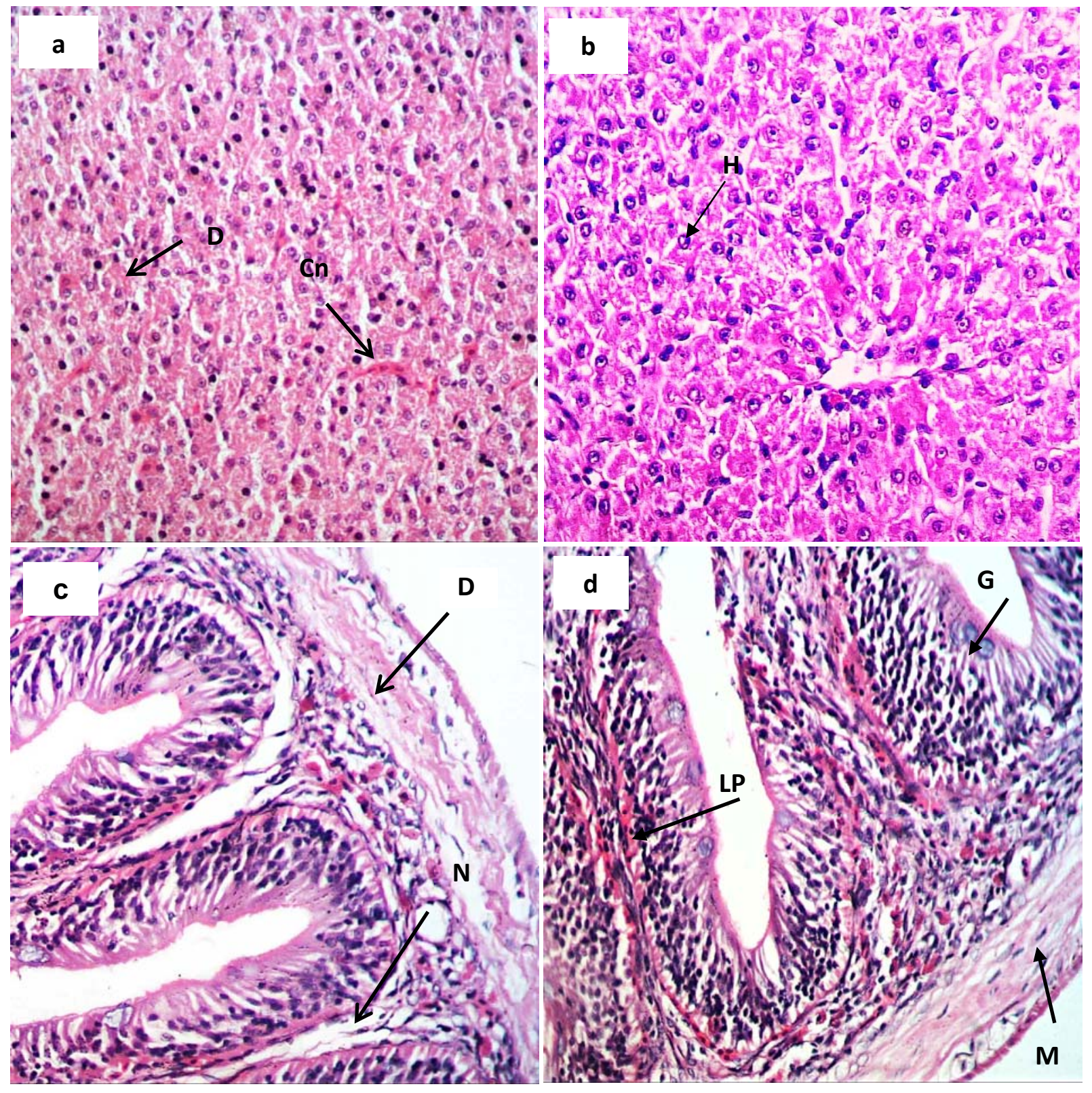

Fig.2. Histoarchitecture of liver and intestine tissues of Nile tilapia fed the control diet and diets supplemented with yeast extract: (a): show congestion $(\mathrm{Cn})$ in blood sinusoids and degeneration (hypotrophy) (D) of hepatocytes of fish fed the control diet; (b): show normal and denser liver morphology of tilapia fed a diet supplemented with yeast extract; (c): shows degeneration (D) and necrosis (N) in sub-mucosal and mucosal morphology respectively of mid-sections of intestine of Nile tilapia fed the control diet; (d): shows a healthier intestine of fish fed a diet supplemented with yeast extract with regular distribution of goblet cells (G) and normal (unbroken) mucosal fold structure and more developed lamina propria (LP) and muscularis (M) layer. 